\title{
Process integration of sodium hypophosphite production
}

\author{
Leonid Tovazhnyansky ${ }^{\mathrm{a}}$, Petro Kapustenko ${ }^{\mathrm{a}}$, Leonid Ulyev ${ }^{\mathrm{b}}$, Stanislav Boldyryev ${ }^{\mathrm{b}, *}$, Olga Arsenyeva ${ }^{\mathrm{b}}$ \\ a National Technical University "Kharkiv Polytechnic Institute", 21 Frunze St., 61002 Kharkiv, Ukraine \\ ${ }^{\mathrm{b}}$ AO SODRUGESTVO - T, Company, 2 per. Krasnoznamenny, Suit 19, 61002 Kharkiv, Ukraine
}

\section{A R T I C L E I N F O}

Article history:

Received 29 August 2009

Accepted 16 April 2010

Available online 24 April 2010

\section{Keywords:}

Process integration

Sodium hypophosphite

Heat exchanger network

Composite curves

\begin{abstract}
A B S T R A C T
The case study of flexible integrated flowsheet development for sodium hypophosphite production is presented. It is based on phosphoric sludge utilization process. The weight concentration of phosphorous in raw materials is equal to $30-50 \%$. The reaction and separation parts of the system were designed based on detailed analysis of production stages. After that the process equipment was selected. Process modelling is made for annual production of hypophosphite equal to $2500 \mathrm{t}$. It permitted to extract process streams for heat energy integration and to define their parameters. The operating pinch procedure was used to estimate the consumption of hot and cold utilities for non-integrated process. The influence of utilities cost on minimal temperature difference is investigated. Analysis of heat system topology modification depending on energy prices is conducted. Optimal structure of heat recovery system and minimal temperature difference are determined. It is shown that optimal integrated process consumes $45 \%$ of hot and $30 \%$ of cold utilities required by non-integrated process.
\end{abstract}

(c) 2010 Elsevier Ltd. All rights reserved.

\section{Introduction}

Nowadays the trend for the production of concentrated and complex fertilizers led to the steady increase in the volume of consumption and production of a phosphoric acid [1,2]. It is produced in industrial scale when a phosphorous containing mineral reacts with a mixture of sulphuric and phosphoric acids. The main by-product of this reaction is the formation of calcium sulphate (gypsum) crystals, which are separated from phosphoric acid at the end of the process together with other by-products formed during the reaction. Such by-products form a phosphorus containing sludge, which is deposited in large amounts upon yellow phosphorus production process industrial sites.

Extraction of phosphorus from its sludge represents an important problem that has several process solutions. One of those is a widely used process of sodium hypophosphite $(\mathrm{SH})$ synthesis employing the method of phosphorus sludge processing with alkali. This method is accompanied by development of waste, namely phosphite-containing slag, which has up to $25 \%$ of yellow phosphorus remnants. Slag (the mixture of $\mathrm{CaHPO}_{3}$ and $\mathrm{CaCO}_{3}$ ) is formed in amount of $3 \mathrm{t} / \mathrm{t}$ of a final product. Its utilization is substantially difficult and involves high energy consumption. The mentioned sodium hypophosphite synthesis process was used in

\footnotetext{
* Corresponding author. Tel.: +380577076001.

E-mail address: stb@kpi.kharkov.ua (S. Boldyryev).
}

particular at the Kazakhstan enterprises. The design of process chemistry was made by VEB Stickctoffwerk Piesteridz (Germany) [3] in 80th years of the last century.

The research presented in this paper originated as a part of a comprehensive European research project ECOPHOS, which is designed to develop ecologically sustainable, environmentally friendly, resource- and energy-saving industrial process technologies for the production of a wide class of phosphorus containing substances, for details see Seferlis et al. [4,5], Papadopulos et al. [6]. In course of the project the design of sodium hypophosphite synthesis chemistry was improved with a considerable increase of phosphorus yield, that is achieved by adjusting the process parameters (in particular ratios of the reagents) with account of specific characteristics of the phosphorus sludge used [7,8]. It became possible with modelling, design and optimisation of industrial production processes technique $[9,10]$.

In considered process the following reactions are taking place:

$$
\begin{aligned}
& 2 \mathrm{P}_{4}+3 \mathrm{Ca}(\mathrm{OH})_{2}+6 \mathrm{H}_{2} \mathrm{O} \rightarrow 3 \mathrm{Ca}\left(\mathrm{H}_{2} \mathrm{PO}_{2}\right)_{2}+2 \mathrm{PH}_{3} \uparrow \\
& \mathrm{Ca}\left(\mathrm{H}_{2} \mathrm{PO}_{2}\right)_{2}+2 \mathrm{NaOH} \rightarrow \mathrm{Ca}(\mathrm{OH})_{2}+2 \mathrm{NaH}_{2} \mathrm{PO}_{2} \\
& \mathrm{P}_{4}+2 \mathrm{Ca}(\mathrm{OH})_{2}+2 \mathrm{H}_{2} \mathrm{O} \rightarrow \mathrm{CaHPO}_{3} \downarrow+2 \mathrm{PH}_{3} \uparrow \\
& \mathrm{NaH}_{2} \mathrm{PO}_{2}+\mathrm{Ca}\left(\mathrm{H}_{2} \mathrm{PO}_{2}\right)_{2} \rightarrow \mathrm{NaCa}\left(\mathrm{H}_{2} \mathrm{PO}_{2}\right)_{3} \downarrow
\end{aligned}
$$




\begin{tabular}{|c|c|c|c|}
\hline \multicolumn{2}{|c|}{ Nomenclature } & \multicolumn{2}{|c|}{ Subscripts } \\
\hline & & & cold utility or stream; \\
\hline C & specific cost of heat carrier, USD/kg & $\mathrm{H}$ & hot utility or stream; \\
\hline$c_{p}$ & specific heat capacity, $\mathrm{kJ} /(\mathrm{kg} \mathrm{K})$ & $\mathrm{HE}$ & heat exchanger; \\
\hline$C_{P}$ & heat capacity flowrate, $\mathrm{kW} / \mathrm{K}$ & $i, j$ & indexes \\
\hline $\mathrm{CW}$ & cooling water & $\min$ & minimal value \\
\hline$G$ & mass flowrate, $\mathrm{kg} / \mathrm{s}$ & REC & recuperation \\
\hline$H$ & flow enthalpy, kW & $\mathrm{S}$ & supply \\
\hline$\Delta H$ & change in flow enthalpy, kW & $\mathrm{T}$ & target \\
\hline$Q$ & heat load, kW & pin & pinch \\
\hline$r$ & latent heat, $\mathrm{kJ} / \mathrm{kg}$ & & \\
\hline$T$ & temperature, ${ }^{\circ} \mathrm{C}$; & \multicolumn{2}{|c|}{ Superscript } \\
\hline$\Delta T$ & temperature difference, ${ }^{\circ} \mathrm{C}$; & $*$ & optimal value \\
\hline$\alpha$ & overall film heat transfer coefficient, $\mathrm{W} /\left(\mathrm{m}^{2} \mathrm{~K}\right)$; & & \\
\hline$\Pi$ & total capitalized value, USD/y; & & \\
\hline
\end{tabular}

$\mathrm{P}_{4}+4 \mathrm{NaOH}+4 \mathrm{H}_{2} \mathrm{O} \rightarrow 4 \mathrm{NaH}_{2} \mathrm{PO}_{2}+2 \mathrm{H}_{2} \uparrow$

$\mathrm{P}_{4}+4 \mathrm{NaOH}+2 \mathrm{H}_{2} \mathrm{O} \rightarrow 2 \mathrm{Na}_{2} \mathrm{HPO}_{3}+2 \mathrm{PH}_{3} \uparrow$

$\mathrm{Ca}(\mathrm{OH})_{2}+\mathrm{Na}_{2} \mathrm{HPO}_{3} \rightarrow \mathrm{CaHPO}_{3} \downarrow+2 \mathrm{NaOH}$

$\mathrm{NaH}_{2} \mathrm{PO}_{2}+\mathrm{NaOH} \rightarrow \mathrm{Na}_{2} \mathrm{HPO}_{3}+\mathrm{H}_{2} \uparrow$

$\mathrm{Ca}\left(\mathrm{H}_{2} \mathrm{PO}_{2}\right)_{2}+\mathrm{Na}_{2} \mathrm{HPO}_{3} \rightarrow \mathrm{CaHPO}_{3} \downarrow+2 \mathrm{NaH}_{2} \mathrm{PO}_{2}$

The process (Fig. 1) consists of several basic stages, as follows: preparation of initial components for SH synthesis and their supply to main reactor (R-4); synthesis of sodium hypophosphite; separation of sodium hypophosphite as the end product (R-6); heat energy supply and cooling $[8,9]$. The aim of preparation stage is to make $\mathrm{NaOH}-\mathrm{Ca}(\mathrm{OH})_{2}$ suspension and to prepare phosphorouscontaining sludge. Suspension of $\mathrm{Ca}(\mathrm{OH})_{2}$ is prepared in reactor R-1 and goes to reactor $\mathrm{R}-3$ as to prepare $\mathrm{NaOH}-\mathrm{Ca}(\mathrm{OH})_{2}$ mixture. Phosphorous sludge after initial reactor $(\mathrm{R}-2)$ is loaded to main reactor ( $\mathrm{R}-4)$ in which also are added $\mathrm{NaOH}-\mathrm{Ca}(\mathrm{OH})_{2}$ suspension and water. Reactors $\mathrm{R}-1, \mathrm{R}-2, \mathrm{R}-3, \mathrm{R}-4$ and $\mathrm{R}-5$ are heated by process steam. Following reactor is cooled by cooling water after reaction completion. Synthesis unit consists of main reactor (R-4) and following reactor (R-5). After filtration (F-1) the obtained solution of $\mathrm{SH}$ is corrected in neutralizer (R-6). Separation stage is the most complicated stage from viewpoint of equipment involved. The objective of separation stage process is to obtain the sodium

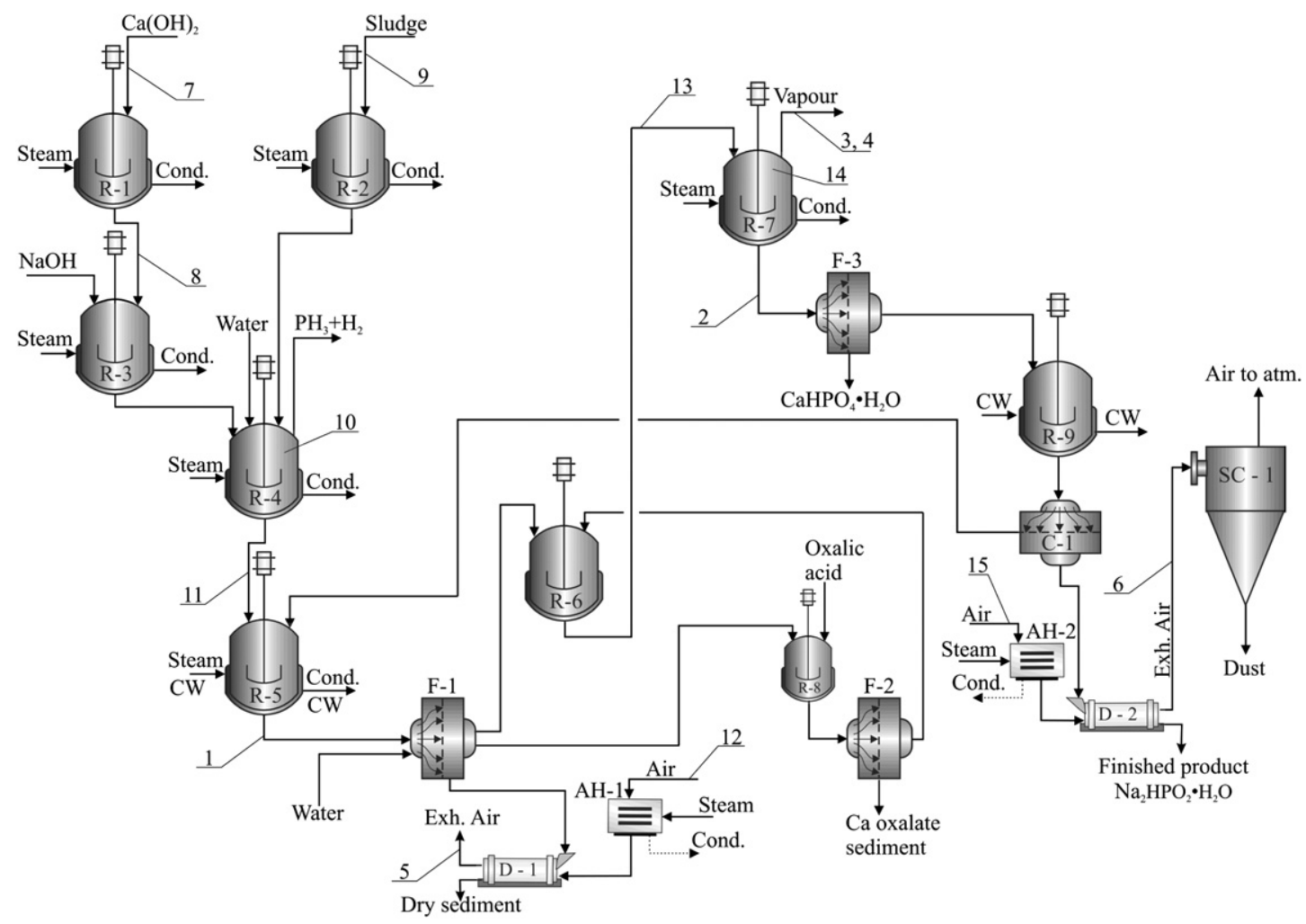

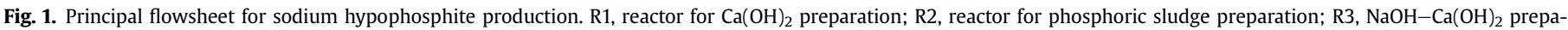

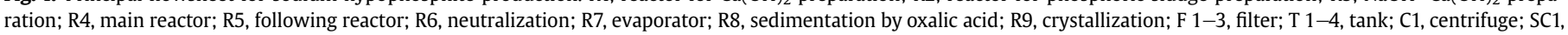
cyclone; D 1,2, dryer; AH 1,2, air heater; CW, cooling water; $1, \ldots, 15$, process streams numbered according to Table 1. 
Table 1

Stream data of sodium hypophosphite production existing process.

\begin{tabular}{|c|c|c|c|c|c|c|c|c|c|c|}
\hline No & Stream name & Type & $T_{\mathrm{S}},{ }^{\circ} \mathrm{C}$ & $T_{\mathrm{T}},{ }^{\circ} \mathrm{C}$ & $G, \mathrm{~kg} / \mathrm{s}$ & $c_{\mathrm{p}}, \mathrm{kJ} / \mathrm{kg} \cdot \mathrm{K}$ & $r, \mathrm{~kJ} / \mathrm{kg}$ & $C_{P}, \mathrm{~kW} / \mathrm{K}$ & $\Delta H, \mathrm{~kW}$ & $\alpha, \mathrm{W} /\left(\mathrm{m}^{2} \mathrm{~K}\right)$ \\
\hline 1 & Cooling after following reactor & Hot & 90 & 25 & 6.13 & 3.56 & & 21.84 & 1420.0 & 100 \\
\hline 2 & Cooling after evaporation & Hot & 90 & 40 & 1.56 & 2.96 & & 4.63 & 231.3 & 100 \\
\hline 3 & Condensation of vapor & Hot & 110 & 110 & 1.91 & & 2230 & & 4266.0 & 1000 \\
\hline 4 & Cooling of condensate & Hot & 110 & 25 & 1.91 & 4.19 & & 8.02 & 681.3 & 100 \\
\hline 5 & Exhaust gas 1 & Hot & 60 & 25 & 21.43 & 1.02 & & 21.86 & 764.9 & 50 \\
\hline 6 & Exhaust gas 2 & Hot & 60 & 25 & 7.21 & 1.02 & & 7.35 & 257.3 & 50 \\
\hline 7 & Heating of $\mathrm{Ca}(\mathrm{OH})_{2}$ solution & Cold & 20 & 50 & 2.71 & 3.35 & & 9.09 & 272.8 & 100 \\
\hline 8 & Heating of $\mathrm{NaOH}-\mathrm{Ca}(\mathrm{OH})_{2}$ suspension & Cold & 20 & 50 & 3.98 & 3.35 & & 13.36 & 400.7 & 100 \\
\hline 9 & Phosphorous sludge preparation & Cold & 20 & 75 & 1.15 & 0.80 & & 0.91 & 50.2 & 100 \\
\hline 10 & Phosphorous sludge decomposition & Cold & 50 & 95 & 7.03 & 3.35 & & 23.55 & 1059.9 & 100 \\
\hline 11 & Heating in following reactor & Cold & 35 & 90 & 6.13 & 2.93 & & 17.99 & 989.3 & 100 \\
\hline 12 & Air to drying 1 & Cold & 20 & 80 & 21.43 & 1.02 & & 21.86 & 1311.3 & 50 \\
\hline 13 & Preheating before evaporation & Cold & 30 & 110 & 3.48 & 3.56 & & 12.38 & 990.3 & 100 \\
\hline 14 & Evaporation & Cold & 110 & 110 & 1.91 & & 2230 & & 4266.0 & 1000 \\
\hline 15 & Air to drying 2 & Cold & 20 & 80 & 7.21 & 1.02 & & 7.35 & 441.2 & 50 \\
\hline
\end{tabular}
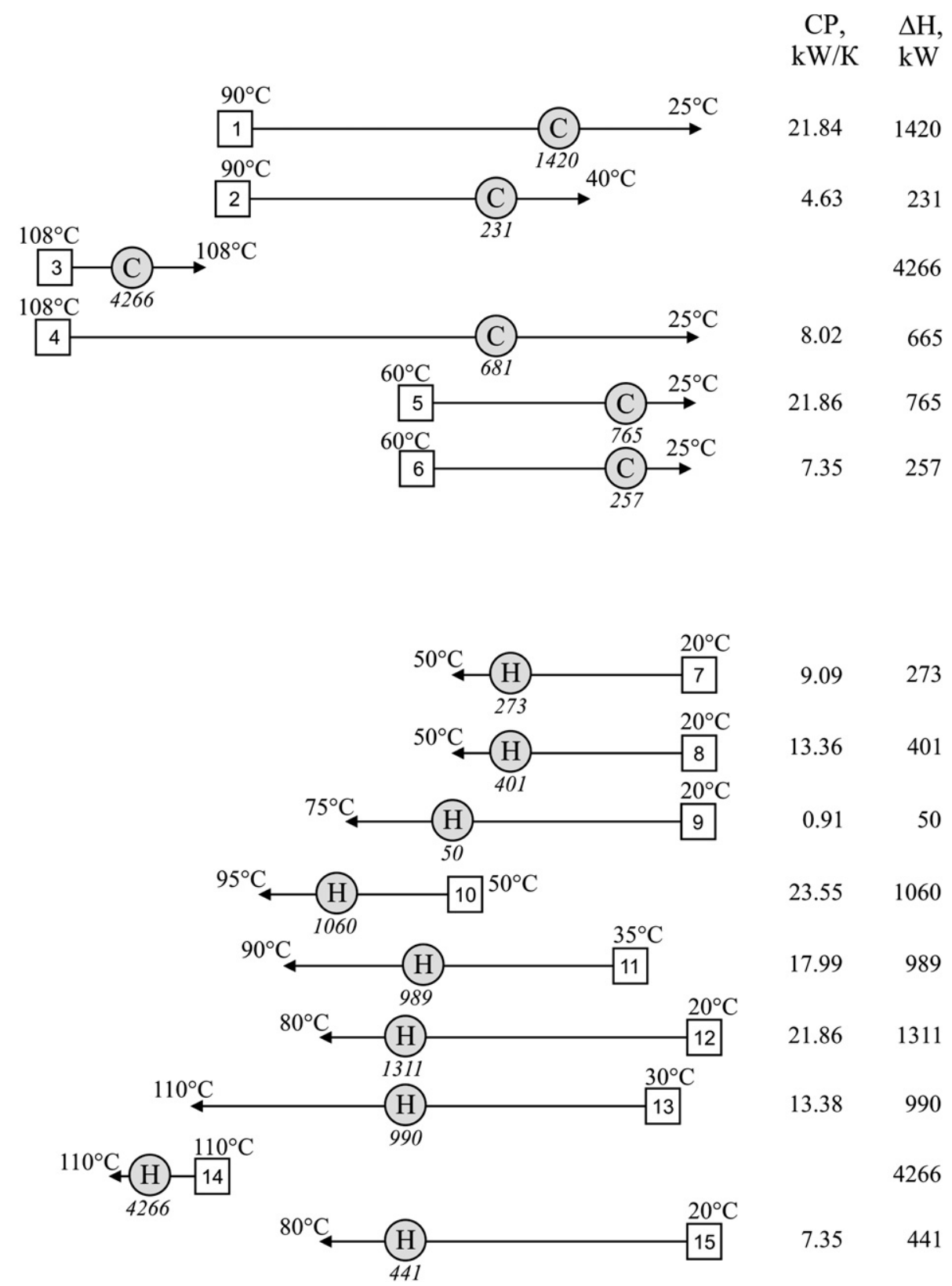

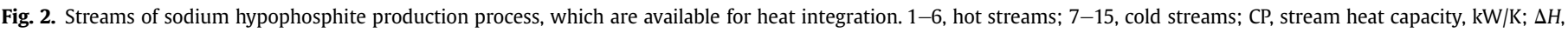
stream enthalpy change, $\mathrm{kW}$. 


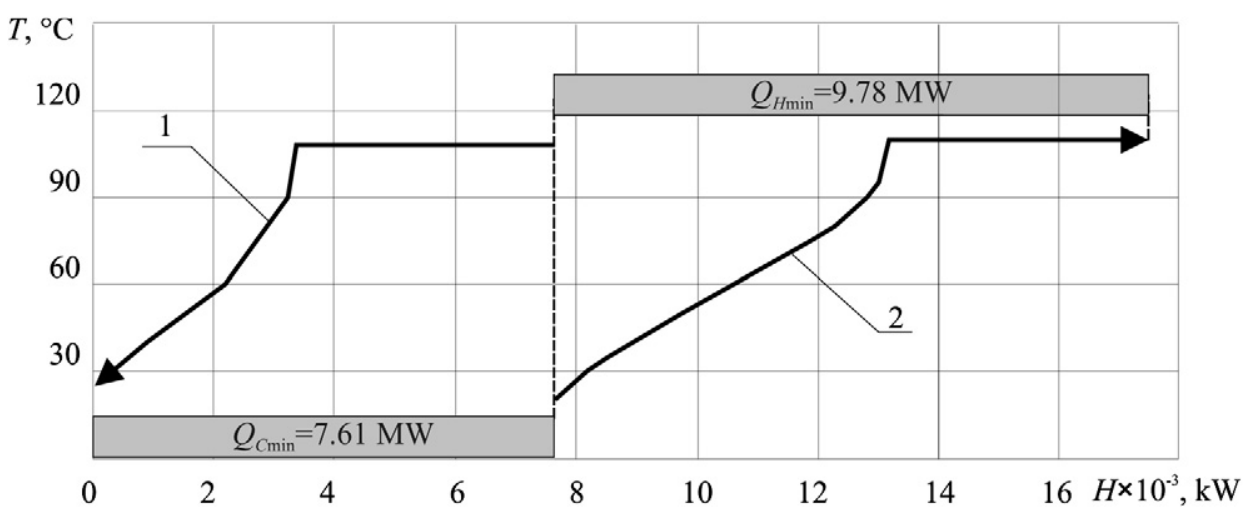

Fig. 3. Composite curves for the proposed process: 1 , hot composite curve; 2 , cold composite curve; $Q_{\text {Hmin }}$, hot utility consumption, kW; $Q_{C m i n}$, cold utility consumption, kW.

hypophosphite of commercial grade from sodium hypophosphate which is coming after synthesis.

The process under investigation is chemical-processing system, which include chemical reaction, separation of obtained products, utility system. The optimisation of process chemistry and separation part gave the possibility to obtain environmentally friendly production, by improving phosphorus yield and minimizing waste. One of the process features is high demand for energy, which can considerably influence the production cost and increase global environmental pollution. To optimise energy consumption it is necessary to estimate possibilities of heat recovery with the use of process integration methods (see e.g. [11-13]). Beside the uncertainties in such factors as mineral characteristics, reactant compositions and process temperature conditions etc., which are inherent to industrial phosphoric acid production processes [14], the optimisation of heat recovery is complicated by uncertainties in energy prices and heat transfer coefficients at different heat transfer equipment items. The influence of these features on optimal process integration solution for particular case study is analyzed below in this paper.

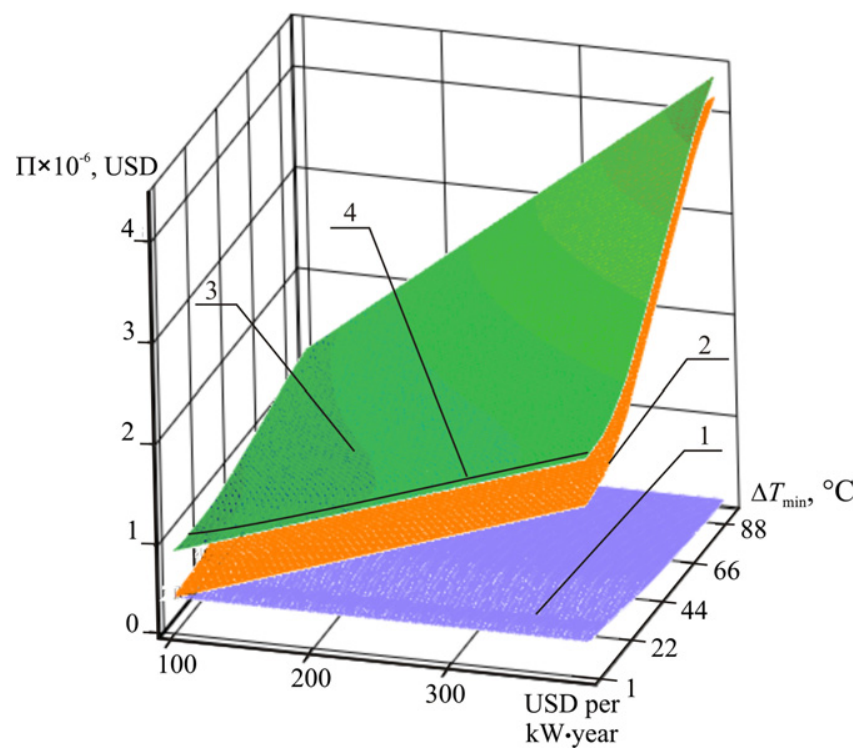

Fig. 4. Capitalized values vs. $\Delta T_{\min }$ and energy price: 1 , capitalized value for equipment; 2, capitalized value for energy; 3 , total capitalized value; 4 , minimal total capitalized value for fixed energy price.

\section{Heat integration of sodium hypophosphite production}

\subsection{Selection of method}

Design of the industrial process heat systems with the minimal energy consumption is one of the most difficult technical problems. The development of optimal heat exchange system requires finding the decision from a huge number of possible options. For example, there are $3 \times 10^{6}$ options of schemes in problem with five cold and hot process streams [15]. The important stage of the decision is the formulation of an objective function. It is frequently as follows [16]:

$\Pi=\left(\delta_{1}+\delta_{2}\right)\left(\sum_{i=1}^{N_{\mathrm{H}}} A_{i}+\sum_{j=1}^{N_{\mathrm{C}}+N_{\mathrm{N}}} B_{j}\right)+\theta \sum_{i=1}^{N_{\mathrm{K}}} \sum_{j=1}^{N_{\mathrm{C}}+N_{\mathrm{N}}} C_{i} \times G_{i j}$

where $\Pi$ is the total capitalized value, USD/year; $\delta_{1}$, normative payback coefficient, year ${ }^{-1} ; \delta_{2}$, depreciation rate, year $^{-1} ; \theta$, duration of equipment annual operation, h/year; $A_{i}$, cost of $i$ th heat exchanger, USD; $B_{j}$, cost of $j$ th heater or cooler, USD; $C_{i}$, cost of $i$ th heat carrier, USD $/ \mathrm{kg} ; G_{i j}$, mass flowrate of $i$ th heat carrier in $j$ th heat exchanger, $\mathrm{kg} / \mathrm{h} ; N_{\mathrm{H}}, N_{\mathrm{C}}, N_{\mathrm{N}}, N_{\mathrm{K}}$ are number of heat exchangers, coolers, heaters and heat carriers, respectively.

Traditional design methods do not allow estimation of the resulting costs before the flowsheet is created. Application of mathematical optimisation methods involve substantial computational difficulties due to the necessity for the solution of mixed integer nonlinear programming (MINLP) problems of big dimension. It causes the creation of local methods, which in many cases do not give universal algorithm and reliable strategy to find global optimum.

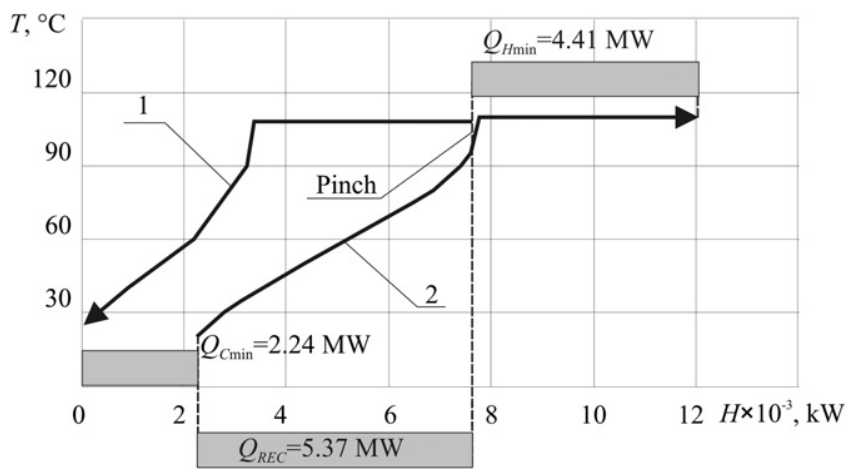

Fig. 5. Composite curves for integrated process at $\Delta T_{\min }=10^{\circ} \mathrm{C}: 1$, hot composite curve; 2, cold composite curve; $Q_{\mathrm{Hmin}}$, hot utility consumption, $\mathrm{kW} ; Q_{\mathrm{Cmin}}$, cold utility consumption, $\mathrm{kW} ; Q_{\mathrm{REC}}$, recuperation duty, $\mathrm{kW}$. 


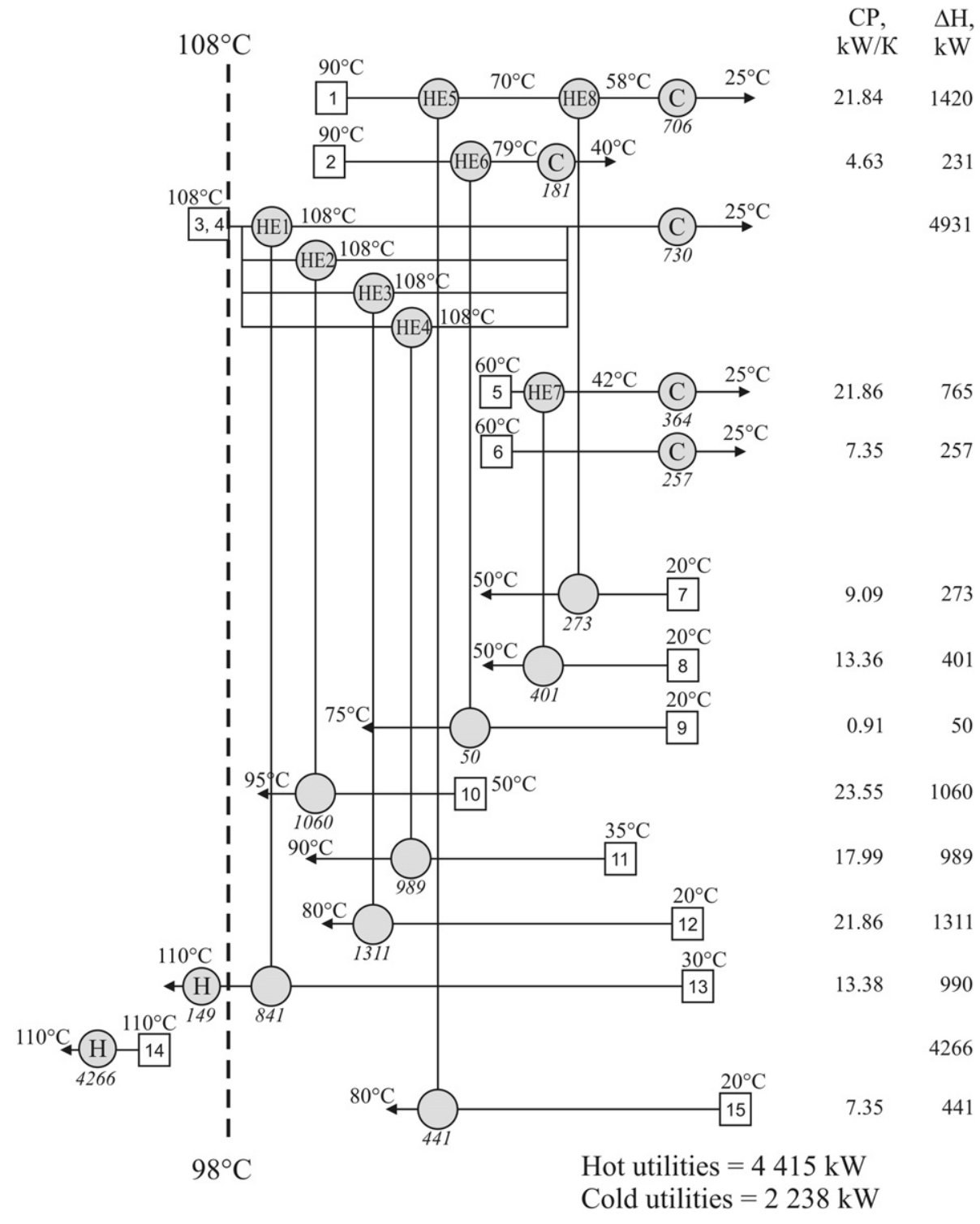

Fig. 6. Grid diagram of integrated process for hypophosphite production with the $\Delta T_{\min }=10^{\circ} \mathrm{C}$.

Professor Bodo Linnhoff and his colleagues at University of Manchester Institute of Science and Technology have developed method of pinch analysis for synthesis of optimal flowsheets (for most recent guidance see [13]). This method is based on thermodynamic analysis of composite curves and enables in rather simple and understandable form to find the solution which is pretty close to optimal. The analysis of energy saving potential for case study of sodium hypophosphite production by this method is presented below.

The general sequence of pinch technology application in our case is as follows:

- data extraction and analysis;

- building of composite curves and grand composite curve for existing process;

- grid diagram design of existing process;

- analysis of existing process;

- selection of optimal $\Delta T_{\min }$;

- building composite curves and grand composite curve for retrofit project;

- grid diagram design for retrofit project;
- calculation of heat exchangers and flowsheet design.

On building the composite curves the temperature of streams with phase change is regarded as constant and it is represented by strictly horizontal lines on temperature-enthalpy diagram. All calculations are made with the use of developed at NTU "KhPI" software [17]. The algorithm and software enables to use different heat transfer coefficient values for the same stream, depending on the type of heat transfer equipment used at specific process position.

\subsection{Data extraction}

Principal flowsheet of sodium hypophosphite production is presented in Fig. 1.

Parameters of technological streams which can be included to process integration were determined with technological schedule literature data [18], accompanied by modelling with UniSim software [19]. The data for process streams, which may be included into heat integration are collected in Table 1 . The composition of streams 


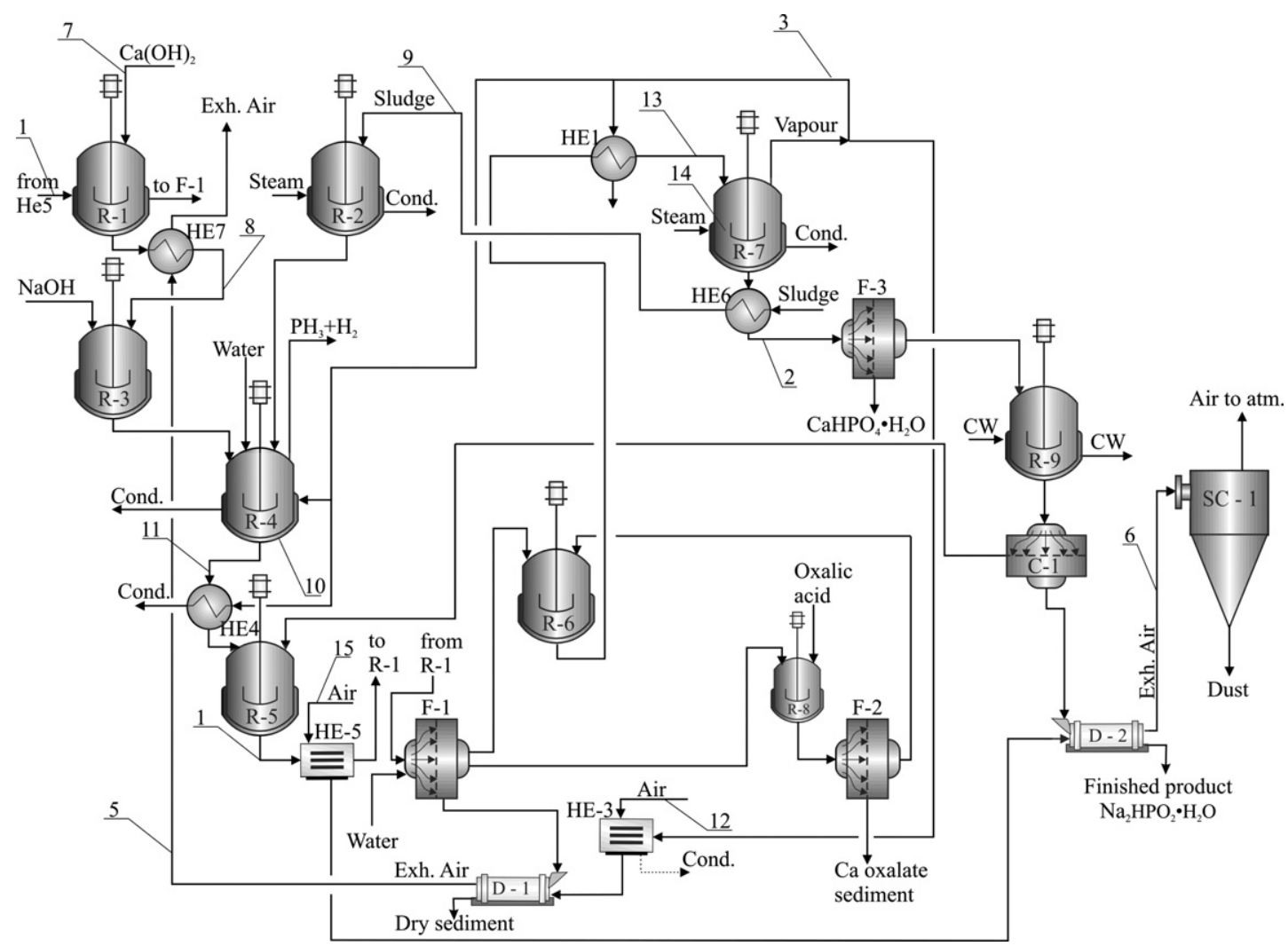

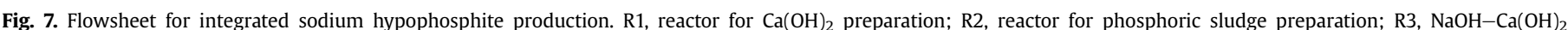

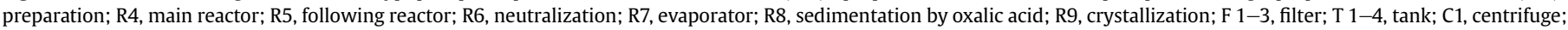
SC1, cyclone; D 1,2, dryer; AH 1,2, air heater; HE, heat exchangers; CW, cooling water; $1, \ldots, 15$, process streams numbered according to Table 1.

presented in Appendix 1. For the analysis of process streams, the grid diagram [11] is used. For existing heat exchangers network it is shown in Fig. 2. The grid diagram reveals no heat recovery of process streams. This can be seen also on composite curves (Fig. 3) of existing sodium hypophosphite production process, which are built based on stream data from Table 1.

Hot utility heat load of considered process is $9781 \mathrm{~kW}$ and cold utility heat duty is $7610 \mathrm{~kW}$. The steam with temperature $130{ }^{\circ} \mathrm{C}$ used as hot utility for indirect heating. The cold utility of existing process is cooling water of cooling tower return cycle with supply temperature of $20^{\circ} \mathrm{C}$.

\subsection{Energy saving potential estimation}

There is no recovery of heat energy between process streams in existing flowsheet. Evidently, it is necessary to build new heat exchanger network on the base of pinch design principles as shown by Linnhoff et al. [20,21]. For grass root design it is required to define $\Delta T_{\text {min }}$ between process streams and targets for cold and hot

Table 2

The parameters estimation for new heat exchangers.

\begin{tabular}{lrrrrrr}
\hline $\begin{array}{l}\text { Heat } \\
\text { exchanger }\end{array}$ & $\begin{array}{l}\text { Heat } \\
\text { load, } \\
\text { kW }\end{array}$ & $\begin{array}{l}\Delta T \text { min Heat } \\
\text { exchange } \\
\text { area, } \mathrm{m}^{2}\end{array}$ & $\begin{array}{l}\text { Price including } \\
\text { installation, } \\
\text { USD }\end{array}$ & $\begin{array}{l}\alpha_{\mathrm{H}}, \mathrm{W} / \\
\left(\mathrm{m}^{2} \mathrm{~K}\right)\end{array}$ & $\begin{array}{l}\alpha_{\mathrm{C}}, \mathrm{W} / \\
\left(\mathrm{m}^{2} \mathrm{~K}\right)\end{array}$ \\
\hline HE1 & 841 & 10 & 329 & 338,800 & 5000 & 270 \\
HE4 & 989 & 18 & 326 & 335,800 & 5000 & 174 \\
HE6 & 50 & 15 & 37 & 46,600 & 195 & 167 \\
HE7 & 401 & 10 & 620 & 630,000 & 100 & 186 \\
Sum & 2,281 & - & 1312 & $1,351,200$ & & \\
\hline
\end{tabular}

utilities. Utility targets can be obtained from composite curves. At first we should build cost curves of sodium hypophosphite production heat system to define optimal value of $\Delta T_{\text {min. }}$. To draw the cost curves it is necessary to know costs of hot utility, cold utility, cost of $1 \mathrm{~m}^{2}$ of heat exchange surface, cost of heat exchanger installation and cost law. Cost of heat exchange surface depends on such factors as stream aggressiveness, impurities, pressure drop and other.

For optimal integration the main economic indicators which influence the project cost should be defined. Cost of hot utilities is

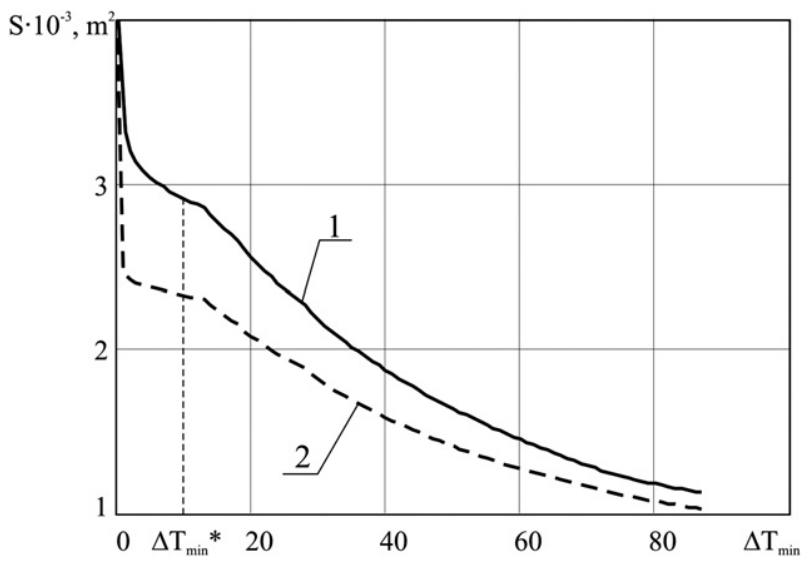

Fig. 8. Dependence of total surface area of heat exchanger network from $\Delta T_{\min }$. 1 , old type heat exchangers; 2, new plate heat exchangers for positions HE1, HE 4, HE 6, HE 7; $\Delta T_{\min }{ }^{*}$, optimal temperature difference of heat exchanger network, ${ }^{\circ} \mathrm{C}$. Note: at $\Delta T_{\min } \rightarrow 0, \mathrm{~S} \rightarrow \infty$. 


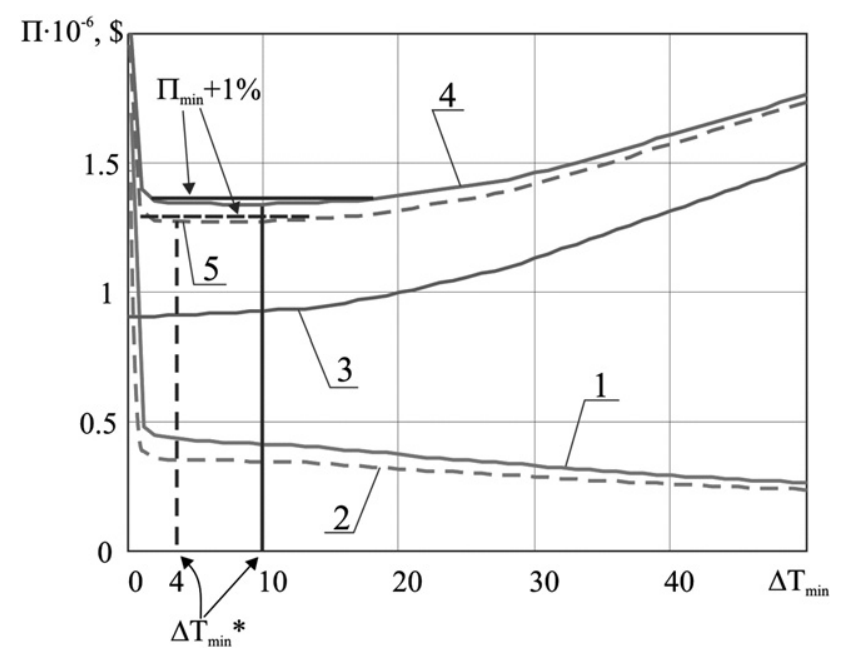

Fig. 9. Capitalized values vs. $\Delta T_{\min }$ and specific energy cost: 1 , capitalized value for equipment for old type heat exchangers; 2 , capitalized value for equipment for new plate heat exchangers; 3 , capitalized value for energy; 4 , total capitalized value for old type heat exchangers; 5 , total capitalized value for new plate heat exchangers; $\Delta T_{\min }{ }^{*}$, optimal temperature difference of heat exchanger network, ${ }^{\circ} \mathrm{C}$. Note: at $\Delta T_{\min } \rightarrow 0$, total capitalized value $\rightarrow \infty$.

taken at $200 \mathrm{USD} / \mathrm{kWy}$, that corresponds to the price of 170 USD for $1,000 \mathrm{~m}^{3}$ of natural gas and for 8000 working $\mathrm{h} / \mathrm{y}$. Cost of cold utilities is accepted as 0.1 from cost of hot utilities, i.e. $20 \mathrm{USD} / \mathrm{kWy}$. Specific price of heat transfer area is taken equal to $1000 \mathrm{USD} / \mathrm{m}^{2}$. Installation costs with repiping of 1 heat exchanger is 10,000 USD. Calculations are made for 5 year contract period and return on capital employed of $10 \%$.

The calculation of the project cost for sodium hypophosphite production allows to define optimal value of minimal temperature difference in heat recovery system, which is equal to $\Delta T_{\min }^{*}=10^{\circ} \mathrm{C}$. Modern tendencies of energy carriers market show the possibility for eventual price rise for some next decades, as was shown by Klemeš et al. [22] and Taal et al. [23]. Therefore it is important to consider the dependence of optimal $\Delta T_{\min }$ in heat recovery system from energy prices. Such analysis made for energy prices in the range from 100 to $400 \mathrm{USD} / \mathrm{kWy}$. Cold utility price varied from 10 to $40 \mathrm{USD} / \mathrm{kWy}$. The plot in Fig. 4 shows that there are some changes of $\Delta T_{\min }^{*}$ localization under energy price variation. Optimal $\Delta T_{\min }^{*}$ is modified within examined range of utility prices. It changes from $18^{\circ} \mathrm{C}$ to $4{ }^{\circ} \mathrm{C}$. But the heat recovery system total capitalized value shows small variations in the range of $\Delta T_{\min } \in 2, \ldots, 18^{\circ} \mathrm{C}$ (in more details for one level of prices see Fig. 9). We can conclude that heat recovery system of sodium hypophosphite production designed for $\Delta T_{\min }=10^{\circ} \mathrm{C}$ will work in mode close to optimal.

The composite curves plotted for $\Delta T_{\min }=10^{\circ} \mathrm{C}$ show the heat power which is needed to be supplied for the integrated process functioning, $Q_{H \min }=4410 \mathrm{~kW}$ (see Fig. 5). This value is on $5371 \mathrm{~kW}$ less than heat load of the process without the recuperation system.

Table 3

The comparison of energy consumptions made for projects with and without heat integration (for energy price 200 USD per $1 \mathrm{~kW}$ year).

\begin{tabular}{lllll}
\hline Project & $\begin{array}{l}\text { Hot } \\
\text { utilities, } \\
\mathrm{kW}\end{array}$ & $\begin{array}{l}\text { Cold } \\
\text { utilities, } \\
\mathrm{kW}\end{array}$ & $\begin{array}{l}\text { Recuperation, } \\
\mathrm{kW}\end{array}$ & $\begin{array}{l}\text { Cost of energy } \\
\text { during the year, } \\
1000 \mathrm{USD}\end{array}$ \\
\hline $\begin{array}{l}\text { Existing process } \\
\text { Integrated process } \\
\Delta T_{\min }=10^{\circ} \mathrm{C}\end{array}$ & $\begin{array}{l}9781.0 \\
7410.0\end{array}$ & 2238.0 & 5371.0 & 2108 \\
$\Delta T_{\min }=4{ }^{\circ} \mathrm{C}$ & 4330.0 & 2163.0 & 5451.0 & 927 \\
\hline
\end{tabular}

Thus process integration reduces heat consumption on $55 \%$, or more than two times. The requirement for cold utilities will be $Q_{\text {cmin }}=2238 \mathrm{~kW}$. It is on $70 \%$ less than that for process without heat integration. Pinch temperature for hot streams is $T_{\text {Hpin }}=108{ }^{\circ} \mathrm{C}$ and for cold streams is $T_{\text {Cpin }}=98^{\circ} \mathrm{C}$. Estimated heattransfer area for heat recovery system is equal to $S=3,050 \mathrm{~m}^{2}$ and number of heat exchangers is 16 .

If to set pinch temperatures of hot and cold streams $\left(T_{\text {Hpin }}=108^{\circ} \mathrm{C}, T_{\mathrm{Cpin}}=98^{\circ} \mathrm{C}\right)$ on the process streams population (see Fig. 6), we can see that all streams are situated below the pinch point except streams Nos. 13 and No.14. Let us to consider pinch temperatures for $\Delta T_{\min }=4^{\circ} \mathrm{C}$, which are equal to $T_{\mathrm{Hpin}}=108^{\circ} \mathrm{C}$, $T_{\text {Cpin }}=104^{\circ} \mathrm{C}$. When to set these temperatures on grid diagram, the structure of the process streams population will and pinch point localization will not change. It means that topology of heat recovery system will be constant for selected variation of $\Delta T_{\mathrm{min}}$.

\subsection{Pinch project for sodium hypophosphite production process}

Problem can be divided at pinch. The cold part has 13 streams, the hot part is simple as it includes two cold streams only. Hot utilities should be placed on these two streams [24]. After the accomplishment of pinch designing for stream system below the pinch point, the grid diagram of heat exchanger network for sodium hypophosphite production process looks like it is shown in Fig. 6.

In obtained design the pinch crossing is absent and earlier defined energy targets are satisfied. Let us build process flowsheet of sodium hypophosphite production using grid diagram. We can use existing heat exchange surfaces. Existing air heaters $\mathrm{AH}-1$ and $\mathrm{AH}-2$ can be utilized on the same positions HE- 3 and HE-5. Stream 7 can be heated via steam jacket of the reactor R-1 by Stream 1 after heat exchanger HE-5. Stream 10 (phosphoric sludge decomposition) is heated by part of Stream 3 in steam jacket of reactor R4. Flowsheet of sodium hypophosphite production with 4 additional heat exchangers is obtained as a result of pinch design with mentioned remarks (see Fig. 7).

The additional plate heat exchangers are calculated using software described by Kapustenko et al. [25]. The calculation algorithms are based on the research results reported in papers for condensation [26], boiling [27] and multicomponent mixtures condensation [28]. The estimated technical-economical characteristics of new heat exchangers presented in Table 2.

The initial estimation of total network heat transfer area is $3050 \mathrm{~m}^{2}$. It is obtained for the values of film heat transfer coefficients found in the literature [18] for heat exchangers used before the retrofit (see the last column in Table 1). The comparison with values presented in Table 2 shows big differences, as plate heat exchangers have much higher heat transfer coefficients. We have made the calculations of total heat transfer surface area with increased values of heat transfer coefficients (as those in Table 2) for heat exchangers on positions HE1, HE4, HE6, HE7. The results of such estimation for total heat transfer area and capitalized value heat exchangers are shown on Figs. 8 and 9. The total heat exchangers network surface area decreased, as also the capitalized value of heat exchangers. At the same time the total capitalized value is lower on $6 \%$ than under the use of less effective old heat exchangers. The optimal value of $\Delta T_{\min }$ becomes equal to $4{ }^{\circ} \mathrm{C}$, compare to initially determined $\Delta T_{\min }^{*}=10^{\circ} \mathrm{C}$. Two horizontal lines $\Pi_{\min }+1 \%$ in Fig. 9 illustrate the levels of total capitalized values, which are on $1 \%$ bigger than their minimal values in each of the cases. With old type of heat exchangers total capitalized value differ from its minimum less than $1 \%$ in the range of $\Delta T_{\min }$ from $2{ }^{\circ} \mathrm{C}$ to $18{ }^{\circ} \mathrm{C}$. For the new type of heat exchangers such range is from $0.7^{\circ} \mathrm{C}$ to $12{ }^{\circ} \mathrm{C}$. But still total capitalized value at $\Delta T_{\min }=10^{\circ} \mathrm{C}$ differ from 
its minimum less than $1 \%$, that can be considered as fairly allowable limit for practical accuracy.

The results presented on Figs. 8 and 9 illustrate the influence of disturbance in overall heat transfer coefficients for the case when more effective equipment with higher heat transfer intensity is utilized. Problem can arise when heat transfer drops due to fouling. To account for this effect initial calculations made for overall film heat transfer coefficients, which values are presented in Table 1. It is conventional approach in literature on process integration, where typical values of overall film heat transfer coefficients for a number of industrial applications are presented (see e.g. [12]). The more precise values accounting for fouling characteristics of different heat exchangers working with various streams can be obtained at detailed network design on a stage of project implementation in industry. It should be done interfacing network synthesis with detailed design of individual heat exchangers, as described in detail by Shenoy [29]. In present study the design of new heat exchangers (see Table 2) was made with software which accounts for fouling in plate heat exchangers.

As one can see, the disturbances in internal system parameters, like fouling and heat transfer coefficients, lead to changes in optimal value of $\Delta T_{\min }$. With change of such external parameter like energy price, optimal $\Delta T_{\mathrm{min}}^{*}$ also varies from $18^{\circ} \mathrm{C}$ (at price $100 \mathrm{USD} / \mathrm{kWy}$ ) to $4{ }^{\circ} \mathrm{C}$ (at $400 \mathrm{USD} / \mathrm{kWy}$ ). As it is shown above, the total cost curve has a relatively flat optimum. Such phenomenon observed for quite a number of process integration problems [12]. It gives a fair amount of freedom in choosing the $\Delta T_{\min }$ for $\mathrm{HE}$ network design. In present case study we have chosen $\Delta T_{\min }=10^{\circ} \mathrm{C}$. It is exact optimal value for energy price $200 \mathrm{USD} /$ $\mathrm{kWy}$ and overall film heat transfer coefficients from Table 1. For other energy prices in examined range the total cost is also very close to optimal. It enables to estimate the benefits which can be achieved with process integration.

The comparison of energy consumption for sodium hypophosphite production with and without recovery system is shown in Table 3. There is significant potential for energy saving using pinch technology. The economy due to the application of energy recovery system is $1,181,000$ USD at energy price $200 \mathrm{USD} / \mathrm{kWy}$ and $\Delta T_{\min }=10^{\circ} \mathrm{C}$. Installation of new recuperative heat exchangers will cost about $1,400,000$ USD and payback period is 14 months. The estimation of energy requirements for $\Delta T_{\min }=4{ }^{\circ} \mathrm{C}$ (see Table 3.) shows just $2 \%$ improvement. It would require $5 \%$ increase of total heat transfer area and respectively rise in investment cost. At the same time the increase of energy price will make proportional rise in economy (to 2,362,000 USD at energy price $400 \mathrm{USD} / \mathrm{kWy}$ and $\left.\Delta T_{\min }=10^{\circ} \mathrm{C}\right)$. Counting for big uncertainties in energy prices which the world experienced recently, the design for $\Delta T_{\min }=10^{\circ} \mathrm{C}$ can be regarded as optimal at available level of prediction for economical factors. This value of $\Delta T_{\min }$ is also satisfying the physical constraints, not jeopardizing the feasibility of the process in any heat exchanger of the network.

\section{Conclusion}

The reported case study has shown considerable potential for energy saving in sodium hypophosphite production, which would also substantially reduce the environmental impact caused by the emissions. Results obtained indicate remarkable improvement in energy usage by the application of process integration techniques. The optimised design is expected to yield reduction 55\% of hot and $70 \%$ of cold utilities. Payback period is close to 14 months, however with the probably to increase if the energy prices this period would be even shortened. The influence of uncertainties in system parameters estimation has been analyzed. The use of heat exchangers with higher heat transfer coefficients, in this case Plate Heat Exchangers, enables to lower capital investment.

\section{Acknowledgements}

The financial support of EC Project ECOPHOS (contract $\mathcal{N} \circ$ INCOCT-2005-013359) is sincerely acknowledged. All authors express thanks to their partners in D. Mendeleyev University of Chemical Technology of Russia provided the industrial data.

\section{Appendix 1. Composition of process streams.}

\begin{tabular}{|c|c|c|c|}
\hline No & Stream name & Components & $\begin{array}{l}\text { Composition } \\
\% \text { (mass) }\end{array}$ \\
\hline \multirow[t]{4}{*}{1} & \multirow{4}{*}{$\begin{array}{l}\text { Cooling after following } \\
\text { reactor }\end{array}$} & $\mathrm{NaH}_{2} \mathrm{PO}_{2}$ & 17.1 \\
\hline & & $\mathrm{Na}_{2} \mathrm{HPO}_{3}$ & 5.2 \\
\hline & & $\mathrm{CaHPO}_{3}$ & 7.6 \\
\hline & & $\mathrm{H}_{2} \mathrm{O}$ & 70.1 \\
\hline \multirow[t]{3}{*}{2} & \multirow[t]{3}{*}{ Cooling after evaporation } & $\mathrm{NaH}_{2} \mathrm{PO}_{2}$ & 57 \\
\hline & & $\mathrm{Na}_{2} \mathrm{HPO}_{3}$ & 9 \\
\hline & & $\mathrm{H}_{2} \mathrm{O}$ & 34 \\
\hline 3 & Condensation of vapor & $\mathrm{H}_{2} \mathrm{O}$ & 100 \\
\hline 4 & Cooling of condensate & $\mathrm{H}_{2} \mathrm{O}$ & 100 \\
\hline \multirow[t]{2}{*}{5} & \multirow[t]{2}{*}{ Exhaust gas 1} & Free air & 96 \\
\hline & & $\mathrm{H}_{2} \mathrm{O}$ & 4 \\
\hline \multirow[t]{2}{*}{6} & \multirow[t]{2}{*}{ Exhaust gas 2} & Free air & 96 \\
\hline & & $\mathrm{H}_{2} \mathrm{O}$ & 4 \\
\hline \multirow[t]{2}{*}{7} & \multirow{2}{*}{ Heating of $\mathrm{Ca}(\mathrm{OH})_{2}$ solution } & $\mathrm{Ca}(\mathrm{OH})_{2}$ & 65 \\
\hline & & $\mathrm{H}_{2} \mathrm{O}$ & 35 \\
\hline \multirow[t]{3}{*}{8} & \multirow[t]{3}{*}{ Heating of $\mathrm{NaOH}-\mathrm{Ca}(\mathrm{OH})_{2}$ suspension } & $\mathrm{NaOH}$ & 31 \\
\hline & & $\mathrm{Ca}(\mathrm{OH})_{2}$ & 22 \\
\hline & & $\mathrm{H}_{2} \mathrm{O}$ & 47 \\
\hline \multirow[t]{3}{*}{9} & \multirow[t]{3}{*}{ Phosphorous sludge preparation } & $\mathrm{P}_{4}$ & 50 \\
\hline & & Mineral part & 10 \\
\hline & & $\mathrm{H}_{2} \mathrm{O}$ & 40 \\
\hline \multirow[t]{5}{*}{10} & \multirow[t]{5}{*}{ Phosphorous sludge decomposition } & $\mathrm{NaH}_{2} \mathrm{PO}_{2}$ & 12.1 \\
\hline & & $\mathrm{Na}_{2} \mathrm{HPO}_{3}$ & 3.7 \\
\hline & & $\mathrm{CaHPO}_{3}$ & 9.9 \\
\hline & & $\mathrm{H}_{2} \mathrm{O}$ & 71.4 \\
\hline & & $\mathrm{PH}_{3}$ & 2.9 \\
\hline \multirow[t]{5}{*}{11} & \multirow[t]{5}{*}{ Heating in following reactor } & $\mathrm{NaH}_{2} \mathrm{PO}_{2}$ & 17.4 \\
\hline & & $\mathrm{Na}_{2} \mathrm{HPO}_{3}$ & 5.3 \\
\hline & & $\mathrm{CaHPO}_{3}$ & 7.9 \\
\hline & & $\mathrm{CaH}_{2} \mathrm{PO}_{2}$ & 0.2 \\
\hline & & $\mathrm{H}_{2} \mathrm{O}$ & 69.1 \\
\hline 12 & Air to drying 1 & Free air & 100 \\
\hline \multirow[t]{3}{*}{13} & \multirow[t]{3}{*}{ Preheating before evaporation } & $\mathrm{NaH}_{2} \mathrm{PO}_{2}$ & 19 \\
\hline & & $\mathrm{Na}_{2} \mathrm{HPO}_{3}$ & 3 \\
\hline & & $\mathrm{H}_{2} \mathrm{O}$ & 78 \\
\hline \multirow[t]{3}{*}{14} & \multirow[t]{3}{*}{ Evaporation } & $\mathrm{NaH}_{2} \mathrm{PO}_{2}$ & 19 \\
\hline & & $\mathrm{Na}_{2} \mathrm{HPO}_{3}$ & 3 \\
\hline & & $\mathrm{H}_{2} \mathrm{O}$ & 78 \\
\hline 15 & Air to drying 2 & Free air & 100 \\
\hline
\end{tabular}

\section{References}

[1] B.M. Beglov, M.K. Zhekeyev, Perspectives of phosphorous, fertilizers, salts production of different application with use of phosphoric acid. Chemical Industry 4 (2002) $1-3$.

[2] Production of phosphoric acid, Booklet No. 4 of 8. European Fertilizer Manufacturers Association, Brussels, 2000.

[3] Estes WE. The method of sodium hypophosphite yield increasing. US patent. 4521391 USA, CA (1985), pp. 423-307 (V.103. P56230П. Cl. C01B, 15/16).

[4] Seferlis P, Klemeš J, Bulatov I, Koltsova E, Kapustenko P, Soboleva I. Development of sustainable processes for waste utilisation in phosphoric acid industry. H8.03. In: Proceedings of the 9th Conference on Process Integration, Modelling and Optimisation for Energy Saving and Pollution Reduction PRES2006/CHISA2006, vol. 4, Prague, (2006) p. 1154.

[5] EU ECOPHOS Project. Available from: <www.ecophos.org > (accessed 10.02.06).

[6] A.I. Papadopoulos, K. Theodosiadis, P. Seferlis, Modeling, design and optimization of industrial phosphoric acid production processes. Chemical Engineering Transactions 12 (2007) 477-482. 
[7] A. Bessarabov, J. Klemeš, A. Kvasyuk, I. Bulatov, CALS software tool for marketing research results of phosphoric industry waste utilisation. Chemical Engineering Transactions 19 (2010) 439-444.

[8] EU ECOPHOS project, Deliverable 1, Available from: <ecophos.org/lib/ ecophos_d1.pdf> (accessed 10/08/2009).

[9] Lisitsina VV. Modeling and optimization of sodium hypophosphite production process. Ph.D. thesis: 05.17.08, MUCTR, Moscow (1994).

[10] A.I. Papadopoulos, P. Seferlis, Generic modelling, design and optimization of industrial phosphoric acid production processes. Chemical Engineering and Processing 48 (2009) 493-506.

[11] B. Linnhoff, J.R. Flower, Synthesis of heat exchanger networks: I. Systematic generation of energy optimal networks. AIChE Journal 24 (4) (1978) 633-642.

[12] J.C. Kemp, Pinch analysis and process integration, in: A User Guide on Process Integration for the Efficient Use of Energy, second ed. Elsevier, Oxford, UK, 2007.

[13] J. Klemeš, F. Friedler, I. Bulatov, P. Varbanov, Sustainability in the Process Industry: Integration and Optimization, first ed., McGraw-Hill Professional, NY, USA, ISBN-13: 9780071605540, ISBN-10: 0071605541, 400 pp.

[14] A.I. Papadopoulos, P. Seferlis, Design of cost optimal and environmentally conscious phosphoric acid production processes under uncertainty. Chemical Product and Process Modeling 3 (1) (2008). doi:10.2202/1934-2659.1248 Article 52.

[15] J. Klemeš, R. Ptáčník, Synthesis of heat transfer optimal structure (in Russian). Theoretical Foundations of Chemical Engineering 21 (4) (1987) 488-498.

[16] V.V. Kafarov, V.P. Meshalkin, V.L. Perov, Mathematical Foundation of Chemical Process Automated Design. Chemistry, Moscow, 1979.

[17] L.L. Tovazhnyanskyy, P.O. Kapustenko, L.M. Ulyev, Energy saving potential definition for industrial sites by composite curves building (in Russian). Integrated Technologies and Energy Saving 1 (1999) 14-27.

[18] EU ECOPHOS Project, Deliverable 8, Available from: <ecophos.org/lib/ ECOPHOS_013359_D8.pdf> (accessed 10/08/2009).
[19] UniSim ${ }^{\circledR}$ Design software, Available from: <Ahpsweb.honeywell.com/Cultures/ en-US/Products/ControlApplications/simulation/UniSimDesign/default.htm>.

[20] B. Linnhoff, S. Ahmad, Cost optimum heat exchanger network - I. Minimum energy and capital using simple model for capital cost. Computers and Chemical Engineering 14 (7) (1990) 729-750.

[21] B. Linnhoff, E. Hindsmarsh, The pinch design method for heat exchanger networks. Chemical Engineering Science 38 (5) (1983) 745-763.

[22] J. Klemeš, I. Bulatov, T. Cockerill, Techno-economic modelling and cost functions of $\mathrm{CO}_{2}$ capture processes. Computers and Chemical Engineering $31(5,6)$ (2007) 445-455.

[23] M. Taal, I. Bulatov, J. Klemeš, P. Stehlik, Cost estimation and energy price forecasts for economic evaluation of retrofit projects. Applied Thermal Engineering 23 (2003) 1819-1835.

[24] E. Rev, Z. Fonyo, Synthesis of heat exchanger network. Chemical Engineering Communications $18(1-4)$ (1982) 97-106.

[25] P. Kapustenko, S. Boldyryev, O. Arsenyeva, G. Khavin, The use of plate heat exchangers to improve energy efficiency in phosphoric acid production. Journal of Cleaner Production 17 (2009) 951-958.

[26] L.L. Tovazhnyansky, P.O. Kapustenko, Intensification of heat and mass transfer in channels of plate condensers. Chemical Engineering Communications 31 (6) (1984) 351-366.

[27] L.L. Tovazshnyansky, P.O. Kapustenko, O.Y. Perevertaylenko, The investigation of flow boiling for flows in channels with cross-corrugated walls. Heat Transfer Engineering 23 (6) (2002) 62-69.

[28] L.L. Tovazshnyansky, P.O. Kapustenko, O.G. Nagorna, O.Y. Perevertaylenko The simulation of multicomponent mixtures condensation in plate condensers. Heat Transfer Engineering 25 (5) (2004) 16-22.

[29] U.V. Shenoy, Heat exchanger network synthesis, Process Optimization by Energy and Resource Analysis. Gulf Publishing Co, Houston, Texas, USA 1995. 